\title{
University Entrance Exams from the Perspective of Senior High School Students
}

\author{
Yüksel Çırak \\ Correspondence: Yüksel Çırak, Faculty of Education, Inonu University, Malatya, İnönü Üniversitesi Merkez Kampüsü, \\ 44280, Turkey.
}

Received: March 7, 2016 Accepted: March 31, 2016 Online Published: July 28, 2016

doi:10.11114/jets.v4i9.1773

URL: http://dx.doi.org/10.11114/jets.v4i9.1773

\begin{abstract}
The aim of this study was to explore senior high school students' feelings and thoughts about the university entrance exam. A total of 23 senior high school students, 14 girls and 8 boys between the ages of 17 and 18, participated in this qualitative study. Research data were collected between February and March 2015 through face to face semi-structured interviews. Three themes were identified as a result of the analysis: "anxiety", "family expectations and responsibilities", and "the door to the future". When participants were asked to think about the university entrance exam, they stated that they experienced fear, despair, concern, helplessness and panic, which are all emotional dimensions of anxiety. Furthermore, some participants perceived the exams as an all-or-nothing issue and felt that the expectations of their families from them create a serious burden on their shoulders. Participants associated university entrance exams with living creatures, objects or characters such as "a dog", "a cactus" or "a bug", to name a few. And finally, participants regarded the exam as a "door" that opens to their future, conceiving it as an opportunity.
\end{abstract}

Keywords: university entrance exam, high school student, adolescence

\section{Introduction}

In Turkey, the number of students is greater than the number of available spaces in higher education programs. As a result, central exam or set of exams have been implemented by the Student Selection and Placement Centre since 1974 (Dökmen, 1992). In Turkey getting into a university through these exams is a long and exhausting process for students. Thus students feel compelled to get prepared to the university entrance exam. They typically start this process at around the ages of 11 or 12 by attending private teaching institutions, called dershane, in addition to their formal education at schools. After getting through the high school entrance exams (TEOG- Transition from Basic to Secondary Education Exam), students are required to gather their strength again within a short period of time in order to prepare for another examination process, whereby they will rush in the triangle of school-private teaching institution-private lesson. The pressure and adversity student associated with this experience is not offset with a successful performance in the exam. Students want to graduate from university programs that will best enable them to gain employment once they have completed their education. Yet, undergraduate programs that promise a high rate of employment opportunities are far more competitive. Every year, the number of individuals taking the university exams is increasing more and more. In 2011, 1,418,914 students applied to the Student Selection and Placement Exam (ÖSYS) and 163,783 students were registered to a four-year undergraduate program at state universities. In 2014, approximately 2,086,115 students applied to the ÖSYS, while only about 330 thousand students were placed in four-year undergraduate programs at state universities (ÖSYM, 2014). In other words, more than two million teenagers were ruthlessly competing to succeed in the university exams. The series of intense emotions that parents and other family members - along with these young people - go through during this period function as one of the main problems of Turkish society. In 2014, senior high school students constituted $40 \%$ of the university entrance examinees (ÖSYM, 2014), while the rest included those who graduated earlier and had been preparing for the exams for 1-5 years. A majority of the university entrance examinees are teenagers aged 17-18. At this particular time in their lives, these students are also passing through critical developmental stages, such as adapting to changes in their body, preparing to depart from their parents, gaining a gradual understanding of independence, questioning values, building up their own life philosophy, exploring intimate personal relationships and choosing a career (Adams, 2000; Gander and Gardiner, 2007; Gerreig and Zimbardo, 2013; Kulaksızoğlu, 2014; Plotnik, 2009). The process of preparing for university and the intense anxiety generated by this process - amidst all the other developmental stages of puberty - may leave teenagers with not enough time to deal with 
other developmental needs. The failed opportunities to adequately fulfil these developmental needs can have serious impacts on the psychological well-being of teenagers. One of the most sensitive steps informing psychological well-being is the process of searching for and creating an identity (Bacanl1, 2003; Gümüşel, 2013; Yazgan-İnanç, Bilgin and Atıc1, 2007). A critical stage of this process is the period of puberty. During this period, the protracted, acute experiences endured in examination expectations and pressure may hinder the possibility of a healthy identity seeking process, part of which includes striving for independence and social reproduction (Siyez, 2009). It is at this point where potential pressures may cause teenagers to become emotionally ill-tempered, to experience problems with social adaptation and to exhibit antagonist behaviour, such as disobedience (Bakırcığlu, 2011; Kulaksızoğlu, 2010; Nelsen and Lott, 2001; Yavuzer, 1997).

In the relevant body of literature in Turkey, there are no studies investigating the feelings and thoughts of high school students' regarding the university entrance exams. Related studies largely focus on subjects like anxiety (Genç et al., 1999; Güneri-Yerin, 2003; Kabalc1, 2008; Kapıkıran, 2002; Kısa, 1996; Yıldırım and Ergene, 2003; Yıldırım, 2000), depression levels of students preparing for the university exams (Yelkenci, 2013; Yıldırım, 2004; Yıldırım, 2007), the effects of private teaching institutions on success in the university exams (Aslan and Öztürk, 2001; Morgil, Y1lmaz and Geban, 2001) and the effects of the university entrance exams on students (Kelecioğlu, 2002). Research shows that exam anxiety and the pursuit of academic success have the most profound impact on teenage developmental problems. In the study carried out by Canat, Uçan and Yazan (2009), exam anxiety was found to be the primary reason - with a rate of 30\% - for teenagers consulting psychological assistance services. Likewise, in Kaya's (2015) study, exam anxiety ranked first among the developmental problem high school students experience. In Atli's (2014) study, however, it was observed that study skills $(78.70 \%)$ ranked first and exam anxiety $(72.30 \%)$ second among the most needed subjects in group guidance practices for primary and secondary school students. The intense pressure on young people preparing for the university exams may lead to the display of "depressive" characteristics in $45 \%$ of students and mild depressive tendencies in 17\% of students (Ergene and Yıldırım, 2004). In evaluating the research conducted in this area, exam anxiety was generally observed to be the primary problem experienced by teenagers preparing for the university exam. Accordingly, long periods of anxiety lead many teenagers to display depressive semptoms or mood characteristics. The effects of the university entrance exam on teenagers have attracted the attention of many scholars; and therefore, has been a frequently addressed research topic. Most of the previous research has been carried out through quantitative methods. The tools of measurement (questionnaires, tests, inventory) used in quantitative methods generally seek to identify the condition and degrees of teenagers' problems through different variables.

It is widely known that university entrance exams constitute one of the main problems faced within the Turkish educational system. Previous research has shown that university entrance exams have many effects on students. To further contribute to the body of research studying the potential effects of university exams on students, this study aims to closely examine the feelings and thoughts of students who are preparing for the university entrance exams. Face-to-face interviews were conducted one month prior to the 2015 university entrance exams to explore these feelings and thoughts in detail. The main purpose of this study is to explore senior high school students' feelings and thoughts about university entrance exam.

\section{Method}

\subsection{Research Design}

The aim of this qualitative research is to explore senior high school students' feelings and thoughts about the university entrance exams. Qualitative studies seek to understand how people interpret their experiences, construct their worlds, and attribute meanings to their experiences (Merriam, 2013). As qualitative research methods enable researchers to study subjects in-depth and in detail (Creswell, 2014; Patton, 2014), these methods were used in the study design to thoroughly study senior high school students' feelings and thoughts about the university entrance exams. The focus of this research was not to raise awareness, although the questions addressed to the participants may have awakened a greater degree of sensitivity regarding the university entrance exam.

\subsection{Participants}

Criteria-based sampling, a purposeful sampling method, was used in this study. In criteria-based sampling, a list of the characteristics determined to be significant for the research is compiled before securing the units that match these characteristics (Merriam, 2013). The criteria used for participation in this research were that students be in their senior year of high school and that they were scheduled to be taking the university entrance exam in one month. The research was carried out in Malatya, a metropolitan city with a population of 740,643 in the eastern Anatolian region of Turkey. Participants were drawn from four different high schools affiliated with the Yeşilyurt province in the Malatya City centre, with one of the high schools being a vocational technical high school and the other three Anatolian High Schools. Anatolian high schools aim to prepare their students to higher Education institutions in accordance with their interests, capabilities and academic achievements. 
All of the participants were students who would be taking the Higher Education Entrance Exam (YGS) in one month, on 15 March 2015. The participants included 14 girls and 8 boys between the ages of 17 and 18 .

\subsection{Data Collection}

Data were collected in February and March of 2015 using a semi-structured interview form. This advanced the following four main questions to identify the feelings, thoughts and behaviour of participants about the university entrance exams: What do you feel when you hear about the university entrance exam? What do you think? How does your body react? Which animal, hero of a tale or object would you associate this exam with? At the end of the form, other questions were presented to ascertain greater insight into these questions and further explore participants' viewpoints. Introductory pre-interview meetings were held with the participants of this research to inform them about the purpose of the study and obtain their oral and written consent through the completion of disclosure forms. Appointments were then scheduled for each participant based on their availability. Official permission was obtained from the related institutions prior to the research. To identify participants, guidance counsellors were consulted after being informed about the aim and stages of the research. The interviews were performed in the office spaces provided by the schools' guidance services. During the interviews, questions were further explained by giving examples to ensure that students responded clearly to the questions presented in the semi-structured interview. It was observed that with the university entrance exam being only one month away, all participants were eager to answer questions and express themselves. Each interview took around 25-35 minutes and was recorded on voice recorders, with the consent of the participants. Following each interview, the voice records were reviewed and certain themes derived from these interviews were analysed to identify strategies to be used in subsequent interviews. The voice recordings were trancribed verbatim. Transcribed texts were subjected to content analysis. After evaluating the first interviews, some of the questions which the students had difficulty in understanding were restructured. On the Participant Interview Form, pseudonyms were used in place of the participants' names to secure their anonymity. Participants had the option of selecting their own pseudonyms. This option was chosen by some and therefore used in the research.

\subsection{Data Analysis}

Interview records were transcribed (each transcritoons took abaut 5or 6 pages) and then analysed through coding in NVIVO-10, a computer program for conducting qualitative data analysis. Initial themes were formed and coded during this process. Once all data collection processes were completed, the data was re-read several times and notes were taken about initial categories (examples and counter-examples). Using the NVIVO-1O data analysis program, the frequency of use of certain words was investigated. Data was analysed using tree diagrams and coloured knot (category) strips. As new relationships emerged from the data, some of the previously identified categories were removed and some of the sub-categories were expanded under main themes until all data analysis was completed. For example, each metaphor raised by the students in reference to university entrance exams was considered as a separate theme. These separate themes were later brought together to enrich and clarify main themes. Data analysis in qualitative research goes hand in hand with other stages of research, such as data collection and writing up (Creswell, 2014). Three randomly selected interview transcriptions and the identified themes were also read by two experts who except researcher in the Department of Psychological Counselling and Guidance, and a consensus on the themes were reached. In qualitative research, all data analysis is content analysis, because at this stage the content of interviews, field notes and documents are analysed (Merriam, 2013). The qualitative researcher responsible for carrying out the content analysis decides what constitutes a pattern and a theme and determines what name to give to this structure (Patton, 2014).

\subsection{Studies on Research Validity and Reliability}

The validity strategies used to ensure the validity of the research were triangulation, member check and thick description (Creswell, 2013). Triangulation refers to the analysis of the same qualitative data independently by two or more people and the subsequent comparison of the findings (Patton, 2014). In this research, interview transcriptions and potential themes were read and agreed upon by two experts who except researcher and who expertise in this area. In member checks, participants are asked to go through the drafts in order to validate that the analysis reflects their perspective, to call attention to any sections which might create problems in the event the research is published and to offer insight into the development of new ideas and interpretations (Patton, 2014). In this research, five participants, whose contact details were obtained beforehand, were asked to read the transcribed interview texts. Participants were asked for their endorsments abaut the completeness and correctness of trancriptions. Lastly, thick description refers to the provision of a detailed description of the participants and the research field by the author in order to better equip the reader with the ability to meaningfully interpret the data (Creswell, 2013). With this strategy, since the researcher directly quotes participants in the analysis findings, their expressions are able to be presented in a clear and concise manner.

It has been shown that reliability can be increased the researcher records field notes to a voice recorder with high sound 
quality and transcribes them into text (Creswell, 2013). In this research, reliability was strengthened in precisely this way; that is, by recording all interviews on a high quality voice recorder and transcribing all voice records after the interviews.

\section{Results}

As a result of this study, which investigated the feelings and thoughts of senior high school students prior to the university entrance exam, three main themes were obtained: anxiety, family expectation and responsibility and the door to future.

\subsection{Anxiety}

A great majority of the participants noted that they felt "anxiety whenever they hear about the exam. When asked what they thought about this exam, for which they had been preparing for a long time and which they would be taking within a month, senior high school students frequently expressed the following emotional dimensions of anxiety: fear, discomfort, concern, despair, alarm and panic. Participants experienced the feelings of anxiety and despair because they did not know how they would cope with their lives if they were unable to achieve the test scores they desired in the university exam. During the interviews, it was observed that some students displayed physical symptoms of anxiety when they heard the word exam. For example, when talking about the exam with Beyza she exhibited such clear signs of panic as to indicate her anxiety: "Extreme stress (laughs). Even now it is happening. I mean, you think, what if I cannot succeed." Ahsen noted specifically that a lot of people were preparing for this exam and succeeding in it was extremely difficult. She expressed her concerns about this challenging exam by saying, "This is a very important exam for me. I need to get a high score. So, there is fear, anxiety, because there are many people competing with me." The recent increasing number of students taking the university entrance exams, as can be seen in the two million who took it in 2014 (ÖSYM, 2014), led students to express that this competition has become even more difficult and frightening. Birgül, who experienced similar anxieties and fears, conveyed, "We are only 18 years old, but we are going to choose our lives. And for this, first we have to pass this exam. I think this is a very exciting and scary situation." Simply put, she felt that since this exam was a big stage, it was both an electrifying and a frightening process.

Participants associated the university entrance exams with objects, characters or living things that they had tagged in their previous experiences of fear, such as "dog", "cactus", "bug" and "Hulk". Şeyda said "I liken it [the exam] to a dog. For example, a dog that chases me. It is always behind me. I mean, I will not be able to do anything without getting over it." In this way, she expressed the feelings of fear and despair. Likewise, Tuğçe stated "I would call the university exam, YGS and LYS, a cactus, because they are things that hurt and make people sad. Because when you get close to a cactus, it hurts when you touch it". In other words, for her, the exam was a stinging and painful process. Merve, another participant, associated the exam with a "poisonous bug", while Umut associated it with "Hulk". Umut elaborated, saying "At the end of the day, Hulk is strong. Likewise, the exam is also difficult." In this way, he associated the university entrance exam with a cartoon character that was strong and destructive.

One of the main reasons of exam-related anxiety is the idea of absolute success or failure. This idea is caused by cognitive distortions, such as "to succeed or not to succeed, that is the question". Serkan reflected on this situation as follows:

"I wonder, what if I cannot get what I want? I mean, there is no middle ground. You have fifty percent chance of success and fifty percent chance of failure. For me, there is no middle ground for this. For me, when I take the exam, I am either going to be successful and do what I want or I will fail."

The interviews for this research were carried out about one month before the university entrance exam. For this reason, during the interviews some of the participants started to become even more anxious when they thought about the fact that they would soon be taking the university exam and having to face their fears. In the process of conducting qualitative research, occasionally some of the participants may resist opening themselves up to the researcher and actively participating in the interview process. However, in this research, the primary difficulty was related to the great deal of detail participants used to express themselves and communicate their emotions. This made the researcher's task of keeping the interview confined within strict bounds challenging. Mustafa expressed that the participants' anxiety and fear increased the nearer the exam date approached:

"In fact, I feel anxious when I think about YGS and LYS, because I know that it is a very difficult exam. And many people put so much effort into this exam. And the concern that this effort may not lead to success is intrinsic to this exam. Of course, I am also worried by the fact that this exam is not too far away and it is getting closer every day. Because the time is running out, I feel anxious as the idea of potential failure comes to my mind."

\subsection{Family Expectations and Responsibilities}

In Turkey, parents perceive the university entrance exams as being the most significant opportunity for securing a better 
future. Naturally, this creates weighty expectations on those students who will take the university entrance exams. Families make efforts to increase their children's motivation for the long and stressful process of the university exams, while at the same time they are trying to deal with their children's normal developmental problems of puberty. These efforts may consequently create serious pressure on students. Some of the students stated that the most important motivation to succeed in the university entrance exams was to pay back all the effort their families made for them. Furkan described the pressure created by such expectations: "People around me, specifically my family, have expectations from me, and I do not want to disappoint them and make them sad. I mean I want to get a good score. I want to be placed in a good [university]. For this, I need to succeed in this exam." In Turkey, parents send their children to institutionalized private teaching organizations, outside of their formal schooling. These institutions are specialized in preparing children for the university entrance exams and they typically charge high fees for their services. Parents in the higher socio-economic class get additional support from paid private teachers, in addition to the private teaching institutions. It is quite clear from this that parents feel the need to make a lot of psychological and economic sacrifices for their children's success in exams in Turkey. These sacrifices may serve to create serious responsibilities and pressures for students, as seen in Furkan's remarks about how he feels the need to pay back his family for all their sacrifices. In elaborating on this, Furkan added, "Ultimately, they (parents) give all this effort for four years to ensure that we get somewhere. And this exam is very important for them too. These (efforts) come to my mind. I think about them". Similarly, Zeliha explained how family expectations created a difficult situation for her:

"I leave my own feelings aside and think, 'How could I let my parents down?' How will I tell them if it goes wrong? What will I say? How will I say that I will prepare again? I mean, sometimes, I say - for instance - what if I take the exam but cannot do it; I think about how I will look at my mother's face."

Some of the participants explained that their parents tried to behave well with them, as they were aware of the difficult circumstances their children faced. These participants also noted that while their parents expressed their expectations in different ways, they would nonetheless tell them not to care too much about the exam; that is, parents told their children that the exam was not that important so that their children would not get upset. Hatice reflected on this situation as follows: "My father told me something like "why are you upsetting yourself this much? Is it more important than you are? You are precious for us I mean, okay'. My father relieved me, but I still want to make them happy. You see, I want them to see that their daughter succeeded in the exam." Birgül described how her family expected her to act like a flawless and "emotionless" "robot" focusing only on its task during the process of preparing for the exam. She said:

"Am I a robot? I am a human being too. I can make mistakes, but there is so much pressure that -as I said before I do not care about people a lot-but at the end there is pressure on you and you are not even aware of it. It really becomes a weight on your shoulders. I mean, you see, you have to do something good; make your family happy. You put in all these years of effort. I particularly worked hard the last two years. The accumulation of all these years, your family's expectations, your teachers' efforts, your own efforts and so on. We have to do something good. You need to satisfy yourself first and then your family. There is really a lot of pressure on you."

Students preparing for the exam perceive their parents' expectations as a duty that has to be carried out. Students held that they felt the need to make serious efforts to pay back the sacrifices their families made. In other words, this exam was a measurement of whether they fulfilled their responsibilities or not, both for themselves and their families. Participants described the heavy pressure created by their sense of responsibilities by using metaphors such as "cat", "seed", "mirror" and "ant". Serkan said, "the thing I would associate [the exam] with would be a mirror. Just like a dressing mirror, it reflects what a person is, both to themselves and to their family." In describing the exam, Tuğba stated, "I would call the exam an ant. It fulfils its duties and it is hard working." In effect, she was describing the exam as a process that needed to be fulfilled by working very hard. Moreover, participants stated that the university entrance exam was a long process, full of surprises. They noted that although they worked for long periods to fulfil their families' and their own expectations, the exam acted like an "ungrateful cat" that does not respond to their efforts. Zeliha explained this situation by saying, "I mean, of course we do get some kind of a return for our efforts. Yet, we cannot get as much as we want. This obviously shows ungratefulness. I will give all my years to it [the exam]."

\subsection{The Door to the Future}

The students preparing for university entrance exams saw this difficult process as a doorway to plan their lives, to gain the chance to stand on their own two feet, and to ready their careers. In the interviews, it was observed that participants had an overall negative set of feelings and thoughts about the university entrance exams. But at the same time, it was also seen that they conceived this exam as a chance to plan their lives, which shows that they had a positive perspective, despite their concerns, towards this exam. Furkan held that the university entrance exam gave him a chance to escape from family pressures and deep stress. More particularly, he said, "It is like a milestone, so to say... after that exam, either a better life awaits me or another round of preparing for the exam again and once more experiencing a stressful 
period of family pressure. It is an exam that can change my life." Most of the participants noted that the university entrance exams constituted a transition point whereby their future was determined. It could be argued that there was the perception that this exam would determine their future jobs, families and ways of life to a great extent. Hatice explained that her own fate was determined by the university entrance exams, saying "Everything is tied to this exam: our future, our fate." Likewise, Tuğçe defined the university entrance exam as "an exam that will determine my future". "It is a very important exam for us," she said. After completion of the university entrance exams, some students choose to attend universities outside their hometown. This gives them the opportunity to stand on their own two feet for the first time, far away from their families. Although for some students it is a difficult situation to adjust to, they still think that it would give them great opportunities to explore freedom and test their own life skills. In discussing the chance of experiencing independence, Berivan explained:

"I can step out of the shadow of my family and I can stand on my own two feet. If I succeed in the exam, neither my mother nor my father will be with me. If I can obtain a career with this exam, then I can stand on my own two feet. I think I can do what I want"

Some of the participants saw the university entrance exams as a transition point that would influence their future. They used the metaphors "door" and "tunnel" to describe this transition. Zeynep defined the university exams as a door with keys, saying "For me, YGS and LYS are doors, doors with keys. I think, God willing, the more I work the more I will be able to turn that key. It is a bridge connecting one environment to another." Mustafa explained that he perceived the university entrance exam as a "bridge" that features difficult barriers but offers a transition to the future. He said:

"I might associate the university exams with a bridge, because these exams act like a bridge that takes us from high school to university, and more importantly, leads us to what we will do in the future. But there are a lot of barriers on this bridge, and we are putting forth all our efforts to overcome these obstacles to the best of our abilities. At the same time, this bridge does not only take us to the university, but also to the career we will have for the rest of our lives. It enables and opens up a new life."

\section{Conclusions and Suggestions}

As a result of this qualitative research, which aimed to explore the senior high school students' thoughts about the university entrance exams, three main themes were identified: "anxiety", "family expectations and responsibilities" and "the door to the future".

It was seen that when the topic of the university entrance exam came up, the participants frequently express their feelings of fear, discomfort, anxiety, despair, alarm and panic, all of which are emotional dimensions of anxiety (Türe et al., 2006; Kavakc1 et al., 2014). As a matter of fact, the presence of an exam itself is a source of anxiety (Şad \& Şahiner, 2016). Some students feel this anxiety so exxessively that they associate exams and failure in exams with "torture", "death", "fear of death" (Karadeniz, Er \& Tangülü, 2014, p. 71, 73). Participants explained that the university exam was a difficult competition where many people have to participate. They expressed serious signs of anxiety about how they would cope with their lives, if the exam results turned out to be negative. Participants associated their emotional situation of anxiety and fear about the exam with living creatures, objects and characters, such as "dog", "cactus", "bug", and "hulk". Parallel to the findings of this research, another study, conducted on the metaphoric perceptions of 8th grade students on the Level Placement Test, (SBS) found that students used 30 metaphors to denote the situation of fear. According to the degree of frequency of use of these metaphors, "death" was the second most used, while ghost/monster was the third (Karadeniz et al., 2014). Research shows that one of the most profound problem areas of puberty is exam anxiety (Atli 2014; Canat, Uçan and Yazan, 2009; Kaya, 2015). During most of the interviews conducted in this research, physical symptoms of anxiety, such as bodily reactions, increased heartbeat, shaking (specifically of the legs), low, shy voice and excessive sweating (Baltaş and Baltaş, 1990), were seen. Baltaş (2006) demonstrated that high school students' anxiety levels about the university entrance exams were extremely high. In his study, where he investigated the anxiety level of 5250 students preparing for the ÖSS (Student Selection Exam), he found that these students' anxiety levels were higher than those seen in general surgery patients. One of the main reasons for participants' anxiety is their tendency towards harbouring the negative alternative (black-white, good-bad) in "Bipolar Thinking" (Goldfried and Sobocinski, 1975). Some of the participants described the university entrance exam in terms of success and failure, with no middle ground. In these cases, the students' anxiety levels were shown to increase.

One of the themes identified as a result of this research was "family expectations and responsibilities". It can be argued that parents and other family members experience exam anxiety and stress in such a way as if they too were going to take the exam along with the student (Kesici, 2008). Participants highlighted the serious economic and psychological sacrifices their parents in particular made during the process of preparing for the exam. They felt that these sacrifices placed a serious weight on their shoulders. Family support creates a feeling of pressure for the student that they have to 
pay back their family. Some participants emphasized that they needed to fulfil this heavy duty not to disappoint their families.

Another theme generated in this research is "the door to the future" theme. One of, if not the most, significant condition for students in Turkey to obtain a professional career is to take the university exams and be placed in a higher education program. Students make departmental choices according to their test scores. When they graduate from these programs, they will most likely work in a career related to their field of study. Considering that careers clearly influence an individual's life, partner selection, work area, way of life, economic income, etc. (Genç, Kaya and Genç, 2007), it can be argued that the university entrance exam acts like a new beginning, a "bridge" and a "door" for the students. Students preparing for the university exams noted that they would have the chance to restructure their lives after the exam. Participants expressed this transformation through the metaphors of "door" and "bridge". For the participants of this research, the university entrance exam is a difficult process involving anxiety and responsibilities. Nevertheless, they explained that they would be relieved once they attained the score they desired. Accordingly, they would have the opportunity to plan their lives and futures independently by escaping from family pressure and standing on their two own feet.

To summarize, it is observed that senior high school students who will take the university exam, experience anxiety in the face of this situation. Part of this anxiety is caused by the fear of not being able to achieve the expected test score. Students associate such types of anxiety to scary living creatures they are acquainted with. Moreover, as students want to satisfy their families' expectations, the thought of not being able to meet these expectations serves as another source of anxiety. Students also, however, see the university entrance exams as a door that opens up to their future.

One of the most significant findings of this research is the fact that taking the university entrance exam worries students. It is known that high levels of anxiety influence success in a negative way. For this reason, students should have recourse to resources that serve to help them decrease their levels of anxiety. At the same time, in this research it is seen that not knowing how to deal with life, when the expected test score is not attained, is a problem. Studies showing different ways students can deal with such a situation may be useful. In the research findings, it was shown that families placed expectations on the students and that the thought of meeting these expectations caused anxiety in the students. Families should be made aware of the serious emotional consequences their expectations have on students and be given the necessary support to reduce their own anxieties they harbour about the exam. Some of the students conceive the exam as simply a matter of success or a failure, constructing certain cognitive distortions in the process. In other words, the exam is interpreted as a zero-sum game. Studies further exploring such cognitive distortions should be carried in order to better understand this matter and thereby give students a broader outlook on the possible impacts of the exam. Students perceive the exam as a chance for their future, although it creates anxiety for them. This is a positive situation for students preparing for the exam. Support programs that serve to enhance and foster such emotions should be carried out. Finally, research findings show that students express their anxiety for the exam through metaphorical concepts. School counsellors might benefit from the use of the findings of this research when working with students with similar problems and teachers too can make use of such metaphors in order to show students that they understand what they are going through.

\section{References}

Adams, G. (2000). Adolescent Development the Essential Readings. Blackwell Publishers Ltd. UK: Oxford.

Altınparmak, S., Taner, Ş., Türk, S. M., \& Eser, E. (2012). Life quality of teenagers in second level İzmir/Bornova State Schools. Journal of Anatolian Psychiatry Anadolu Psikiyatri Dergisi, 13, 167-173.

Arslan, M., \& Öztürk, A. (2001). Private teaching institutions' test score returns for students who could not succeed in their first ÖSS. Education Research, 5, 15-20.

Atli, A. (2014). Analysis of need for group works in primary and secondary schools from the perspective of student, teacher and parent. Kastamonu Journal of Education, 23(3), 1347-1362.

Bacanlı, H. (2003), Development and learning [Gelişim ve Öğrenme]. 7th edition, Nobel Publishing, Ankara

Bakırcıŏlu, R. (2011). Psychological Health in Children and Teenagers [Çocuk ve ergende ruh sağlı̆̆1] (Fourth Edition). Ankara: Anı Publishing.

Baltaş, A. (2006). Learning without being overwhelmed under stress and outstanding success in exams [Stres altında Ezilmeden Öğrenmede ve Sınavlarda Üstün Başar1] (24th edition). Remzi Publishing: İstanbul.

Baltaş, A., \& Baltaş, Z. (1990). Stress and Coping with it [Stres ve Başa Çıkma Yolları] (9th edition). İstanbul: Remzi Publishing.

Canat, S., Uçan, Ö., \& Yazar, H. (2009). The period of puberty as an experience of crisis and experiencing crisis during 
puberty. The Journal of Crisis, 17(3), 1-8.

Creswell, J. W. (2013). Qualitative Research Methods: Qualitative Research and Research Design According to Five Approaches [Nitel araştırma yöntemleri beş yaklaşıma göre nitel araştırma ve araştırma deseni] (C. Soydemir, Translated.) Ankara: Siyasal.

Creswell, J. W. (2014). Research Design: Qualitative, Quantitative and Mixed Methods Approaches [Araştırma deseni; niteli nicel ve karma yöntem yaklaşımları] (S.B. Demir, Translated.) Ankara: Eğiten.

Dökmen, Ü. (1992). Turkish Republic higher education council student selection and placement centre, its establishment, development and functioning. [T.C. yükseköğretim kurulu öğrenci seçme ve yerleştirme merkezi, kuruluşu, gelişmesi, çalışması]. Ankara, ÖSYM Publishing.

Gander, M. J., \& Gardiner, H. W. (2007). Child and Teenager Development [Çocuk ve ergen gelişimi](6 b.). (B. Onur, Dü., A. Dönmez, H. N. Çelen, ve B. Onur, Translated by.) Ankara: İmge Publishing house.

Genç, G., Kaya, A., \& Genç, M. (2007). Factors affecting career choice of medical students at İnönü University. İnönü University Journal for the Faculty of Education, 8(4), 49-63.

Genç, M., Karlıdağ, R., Eğri, M., Güneş, G., Kurçer, M. A., Pehlivan, E., Özcan, E., \& Ünal, S. (1999). Anxiety levels of students who will take the student selection exam, Journal of Turgut Özal Medical Centre, 6(1), 37-41.

Gerrig, R. J., \& Zimbardo, P. G. (2013). Introduction to Psychology: Psychology and Life [Psikolojiye Giriş: Psikoloji ve Yaşam] (G. Sart, Translated by.) Nobel, Ankara.

Goldfried, M. R., \& Sobocinski, D. (1975). Effects of irrational beliefs on emotional arousal. Journal of Consulting and Clinical Psychology, 43(4), 504-510. http://dx.doi.org/10.1037/h0076787

Gümüşel, O. (2013). We are Young [Genciz biz] (First edition). İstanbul: Timaş Publishing.

Güneri, Y. O. (2003). The effect of school level and gender on test anxiety. Education and Science, 28(128), 3-8.

Kabalc1, T. (2008). Self-respect, Exam Anxiety and Socio-demographic variables as Indicators of Academic Success (Unpublished Master's Thesis). Hacettepe University, Ankara.

Kapıkıran, Ş. (2002). An investigation on the relationship of university students' exam anxiety with some psycho-social variables. Pamukkale University Journal for the Faculty of Education, 1(11), 35-43.

Karadeniz, O., Er, H., \& Tangülü, Z. (2014). 8th graders' metaphorical perceptions towards the SBS. International Euroasian Journal of Social Sciences, 5(15), 64-81.

Kavakc1, Ö., Semiz, M., Kartal, A. D., \& Kuğu, N. (2014). Test anxiety prevalence and related variables in the students who are going to take the university entrance examination. The Journal of Psychiatry and Neurological Sciences, 27(4), 301-307.

Kaya, M. (2015). Developmental and traumatic problems experienced by high school students: from the perspectives of parents, teachers and students (Unpublished Master's Thesis). İnönü University, Malatya.

Kelecioğlu, H. (2002). Secondary school students' views about the university entrance exams and the effects of the exam on their education. Hacettepe University Journal for the Faculty of Education, 23, 135-144.

Kesici, Ş. (2008). Sixth-seventh, and eighth-grade students' guidance and counselling needs according to parents' views. Eurasian Journal of Educational Research, 32, 101-116.

K1sa, S. S. (1996). The relationship between exam anxiety of senior high school students continuing private teaching institutions in Izmir city centre and parent attitude (Unpublished Master's Thesis). D.E.Ü. Institute of Social Sciences.

Kulaksızoğlu, A. (2010). Developmental Features of the Teenager [Ergenin gelişim özellikleri] in N. Türkyılmaz (Ed.), Parents' Approaches in Child and Teenager Education [Çocuk ve ergen eğitiminde anne baba tutumları] (pp:93-125) (2nd edition). İstanbul: Timaş Publishing

Kulaksızoğlu, A. (2014). The Psychology of Puberty [Ergenlik psikolojisi] (16.Baskı). İstanbul: Remzi Publishing house.

Merriam, S. B. (2013). A Guide to Qualitative Research Design and Application [Nitel araştırma desen ve uygulama için bir rehber]. (S. Turan, Translated. Ed.) Ankara: Nobel.

Ministery of National Education Anatolian High School Regulation (1999). Official Newspaper, number 2386.

Morgil, İ., Y1lmaz, A., \& Geban, Ö. (2001). The effects of private teaching institutions on students' success to be placed in universities. Hacettepe University Journal for the Faculty of Education, 21, 89-96. 
Nelsen, J., \& Lott, L. (2001). Positive Discipline for Teenagers [Ergen gençler için pozitif disiplin] (B. Öztürk, Translated.). (First Edition), İstanbul: Beyaz Publishing.

Patton, M. Q. (2014). Qualitative Research and Methods of Evaluation [Nitel araştırma ve değerlendirme yöntemleri]. (M. Bütün, S. B. Demir Translated) Ankara: Pegem.

Plotnik, R. (2009). Introduction to Psychology [Psikoloji'ye Giriş] (T. Geniş, Translated), (1st Edition). Kaknüs, İstanbul.

Şad, S. N., \& Şahiner, Y. K. (2016). Students' Teachers' and Parents' Views about Transition from Basic Education to Secondary Education (BESE) System. Elementary Education Online, 15(1), 53-76.

Siyez, D. M. (2009). Problematic Behaviours in Teenagers [Ergenlerde problem davranışlar] (1st Edition). Ankara: Pegem A Akademi.

Türe, M., Aktürk, Z., Kurt, İ., \& Dağdeviren, N. (2006). The effect of health status, nutrition, and some other factors on low school performance using induction techniques. Trakya University Journal for the Faculty of Medicine, 23(1), 28-38.

Yavuzer, H. (1997). Children's' Psychology [Çocuk psikolojisi] (14th edition). İstanbul: Remzi Publishing house.

Yazgan-İnanç, B., Bilgin, M., \& Kılıç-Atıc1, M. (2007). Development Psychology: Child and Teenager Development [Gelişim psikolojisi çocuk ve ergen gelişimi] (2nd edition). Ankara: Pegem Publishing.

Yelkenci, İ. (2013). Investigating the anxiety levels of students preparing for the university exams according to various variables (Unpublished Master's Thesis). İstanbul Arel University, İstanbul.

Yıldırım, İ. (2000). Level of loneliness, exam anxiety and social support as indicator of academic success. Hacettepe University Journal for the Faculty of Education, 18, 167-176.

Yıldırım, İ. (2004). Exam anxiety, daily problems and social support as indicators of depression. Hacettepe University Journal for the Faculty of Education, 27, 241- 250.

Yıldırım, İ. (2007). Exam anxiety and social support in Turkish students preparing for the university exam. Eurasian Journal of Educational Research, 29, 171-184.

Yıldırım, İ., \& Ergene, T. (2003). Exam anxiety, obedient behaviour and social support as indicators of senior high school students' academic success. Hacettepe University Journal for the Faculty of Education, 25, 224-234.

This work is licensed under a Creative Commons Attribution 3.0 License. 